\title{
Discourse analysis of religion and inter-communal conflicts and its causes in Nigeria
}

\begin{tabular}{|c|c|}
\hline \multicolumn{2}{|c|}{$\begin{array}{l}\text { Authors: } \\
\text { Christopher N. Ibenwa } \\
\text { Favour C. Uroko }\end{array}$} \\
\hline \multicolumn{2}{|c|}{$\begin{array}{l}\text { Affiliations: } \\
\text { }{ }^{1} \text { Department of Religion and } \\
\text { Cultural Studies, Faculty of } \\
\text { Social Sciences, University of } \\
\text { Nigeria, Nsukka, Nigeria }\end{array}$} \\
\hline \multicolumn{2}{|c|}{$\begin{array}{l}\text { 2Department of New } \\
\text { Testament and Related } \\
\text { Literature, Faculty of } \\
\text { Theology and Religion, } \\
\text { University of Pretoria, } \\
\text { Pretoria, South Africa }\end{array}$} \\
\hline \multicolumn{2}{|c|}{$\begin{array}{l}\text { Research Project Registration: } \\
\text { Project Leader: E. van Eck } \\
\text { Project Number: } 2400030\end{array}$} \\
\hline \multicolumn{2}{|c|}{$\begin{array}{l}\text { Description: } \\
\text { This research is part of the } \\
\text { research project 'Hermeneutics } \\
\text { and Exegesis' directed by Prof. } \\
\text { Dr Ernest van Eck, Department } \\
\text { of New Testament and Related } \\
\text { Literature, Faculty of Theology } \\
\text { and Religion, University of } \\
\text { Pretoria. }\end{array}$} \\
\hline \multicolumn{2}{|c|}{$\begin{array}{l}\text { Corresponding author: } \\
\text { Favour Uroko, } \\
\text { favour.uroko@unn.edu.ng }\end{array}$} \\
\hline $\begin{array}{l}\text { Dates: } \\
\text { Received: } 12 \mathrm{~J} \\
\text { Accepted: } 24 \mathrm{~J} \\
\text { Published: } 08\end{array}$ & $\begin{array}{l}\text { une } 2019 \\
\text { an. } 2020 \\
\text { June } 2020\end{array}$ \\
\hline \multicolumn{2}{|c|}{$\begin{array}{l}\text { How to cite this article: } \\
\text { Ibenwa, C.N. \& Uroko, F.C., } \\
2020, \text { 'Discourse analysis of } \\
\text { religion and inter-communal } \\
\text { conflicts and its causes in } \\
\text { Nigeria', HTS Teologiese } \\
\text { Studies/Theological Studies } \\
\text { 76(4), a5617. https://doi.org/ } \\
\text { 10.4102/hts.v76i4.5617 }\end{array}$} \\
\hline \multicolumn{2}{|c|}{$\begin{array}{l}\text { Copyright: } \\
\text { (c) 2020. The Authors. } \\
\text { Licensee: AOSIS. This work } \\
\text { is licensed under the } \\
\text { Creative Commons } \\
\text { Attribution License. }\end{array}$} \\
\hline \multicolumn{2}{|l|}{ Read online: } \\
\hline 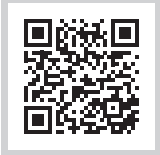 & $\begin{array}{l}\text { Scan this QR } \\
\text { code with your } \\
\text { smart phone or } \\
\text { mobile device } \\
\text { to read online. }\end{array}$ \\
\hline
\end{tabular}

The religious crisis in Nigeria dates back to the colonial era. The amalgamation of two distinct nationalities (Northern and Southern Nigeria) for the purpose of administrative convenience by the colonial government, irrespective of their cultural and educational differences, not only created a hitch in assimilation but also mistrust and bitter rivalry that has accentuated to conflict. In the same vein, most of the communal crises taking place today could be traced to colonial making as they created artificial boundaries that did not take cognisance of kith and kin, consanguinity and linguistic identity. It rather brazenly demarcated people to suit their exploitative governance. The above built-up grievances and tensions spark off a crisis at the slightest provocation or misunderstanding. The objectives of the study are as follows: (1) to identify the factors responsible for the crises, (2) to trace and analyse the antecedents of the crises, and finally (3) to proffer solutions to this seemingly intractable national problem. The methodology adopted for the study is the qualitative phenomenological approach, whereby data were collected from secondary sources and treated analytically. The work found that religion and intercommunal conflict have hindered sustainable development, taking a large toll of lives and property amongst others.

Keywords: religion; communal; conflict; intractable; Christianity; Islam; Nigeria.

\section{Introduction}

Religious-motivated inter-communal conflict has become quite common in Nigeria today. Affirming this view, Bourdillion (1990:183) averred that it appears conflict sometimes arises precisely over religion and that religion therefore creates conflict. The conflict has been between Christianity and Islam. The frequency with which it occurs leads to wanton destruction of lives and property on a very large scale (Nwachukwu \& Ibenwa 2011). The spate at which these conflicts are occurring is alarming and this is portraying Nigeria as a hostile nation. Anugwom and Oji (2004) opined as follows:

$[T]$ hroughout recorded history in West Africa and indeed black Africa in general, Nigeria seems to rank top among the list of an unprecedented upsurge of ethnic and religious disturbances in contemporary times. The situation has remained a constant threat to peace in Nigeria. The vigour it has assumed, has therefore, continued to threaten the nationalities that make up the country as a single sovereign democratic entity. (p. 14)

Therefore, this has become a source of great worry to concerned Nigerians.

The purpose of this study was not only to point out the factors responsible for crises and to trace and analyse the antecedents of the crises but also to proffer solutions to this seemingly intractable national malady of Nigeria. The methodology adopted for the study was the qualitative phenomenological approach, whereby data were collected from secondary sources. A critical discourse analysis was conducted on the research with no bias.

The terms, 'conflict' and 'religion' have been severally defined by different scholars at various times under different historical, ideological and cultural influences. This means that there is no one universally accepted definition of 'conflict' and 'religion'. However, Francis (2007) defined 'conflict' as, 'the pursuit of incompatible goals and interests by different groups'. Phil-Eze (2009) stated that conflict is:

$[A] \mathrm{n}$ expression of disagreement over something important to two individuals, groups, states or nations when they have different views, different goals, different needs, and different values and they fight over limited resources to address them. (p. 393) 
Simply put, conflict is disagreement between two individuals, groups, states or nations in their pursuit of incompatible interests. Bouquet (1941:183) defined 'religion' as, 'a fixed relationship between the human self and some non-human entity, the sacred, the supernatural, the self- existent, the absolute or simple, God'. Another definition by James (2018) sees religion as:

relatively bounded system of beliefs, symbols and practices that addresses the nature of existence through communion with others and Otherness, lived as both taking in and spiritually transcending socially grounded ontologies of time, space, embodiment and knowing. (p. 70)

Religion is better described as man's awareness of the existence of a supernatural being whom she/he believes to be his creator and controller of the universe and his willingness to worship him through an intermediary in solitariness and context of group.

\section{Methods of data collection and analysis}

Data for this study were collected using secondary sources. The secondary sources included, amongst others, materials such as textbooks, journal articles, encyclopaedia and Internet material. These materials helped the researchers to make a qualitative analysis of the issues involved in the topic. The study adopted the qualitative and phenomenological methods in the analysis of data. The qualitative and the phenomenological methods helped the researchers to make unbiased and valid deductions from the documentaries as they related to those religions and communities that were involved in religious and intercommunal conflicts. Elements that were responsible for the crises were identified and discussed critically. At the end, suggestions were made that would create healthier relationships between religions and communities involved in conflicts.

\section{Factors responsible for religion and inter-communal conflicts in Nigeria}

Adejo (2002:248) observed that each conflict does not just happen in a normal manner, they are rooted in some basic dissatisfaction or grievances which await detonation at the slightest opportunity. In fact, conflicts characterise social relations in Nigeria, and some factors are responsible for this development. The factors are many, some of which are sectarian, others are products of unresolved political differences, perceived social marginalisation, unhealthy socio-economic relations and local governments and relocation of markets (Adetula \& Dung 2006 in Abada 2009). Different factors are treated as follows.

Relocation of Market: This is what governments at all levels occasionally do in order to decongest highly populated area to develop another area that is less busy. However, when this is carried out without the due approval of the groups that are involved, it usually leads to resistance and eventual war. Corroborating this view, Okwueze (1995) said that the ZangoKafaf (Kaduna religious riots of 1992) between the two groups was the result of the relocation of a market by local government.

The imposition of Sharia is one of the factors that encouraged fanatics and gave legitimacy to Islamic fundamentalism. Of a truth, the imposition of Sharia by government in most states in northern Nigeria was marked by widespread violence in Zamfara, Kaduna and Kano, to mention but a few (Ibenwa \& Ayogu 2010).

Colonialism: The way the British government restructured Nigerian society on their arrival, left much to be desired. Some of the rearrangements were carried out without the consent of the parties involved. The result of this was that when they left, problems began to manifest here and there unabated. In addition to this, the two foreign religions of Christianity and Islam exacerbated the problem by their frequent crises that lead to loss of lives and property worth millions and billions of naira. This is in line with what Ekwunife (1992) argued that the seeds of religious intolerance in Nigeria were quietly sown through the agencies of colonialism, Islam and Christianity. The British colonial masters with their policy of indirect rule in Nigeria tried to favour some groups and tribes at the detriment of others; hence, some people began to see themselves as being superior to others. So with the departure of colonialists, this began to create animosity and rancor, which sometimes culminated into war. Affirming this, Ugwu (2009) commented that one of the principal and outstanding factors fanning the embers of religious crisis in our nation, and which has continued to fuel it in Kano and Kaduna states, is the colonial government's support and favouritism.

Another area that always generates tension is the issue of indigene and strangers., Tension has persisted because of economic or political hegemony of settlers, which is vehemently resisted by natives, who put in their might to prove the ownership of their lands. Of course, this promotes their primordial ties and makes it to be stronger; however, on the other way round it heats up polity by generating ethnic or identity conflict. Anugwom and Oji (2004) wrote that beginning from the colonial era, the Northern religion manifested signs of ethno-religious divergence, as there was a rigid distinction in interaction and residence between the indigenes and those from outside the religion. Okpara (2013) opines as follows:

Boko-Haram is a euphemism for the Islamic extremist daredevil group set to torpedo the President Goodluck led government, and a strategy and tactics to continue a northern hegemonic hold on the country. (p. 27)

The next causative factor in communal conflict is poverty, particularly amongst the indigenes. This has always increased tension in the relationship between the two parties - the natives who always feel exploited or dispossessed or deprived, hence jealous of the strangers or settlers, for example, Ife-Modakeke and Awka/Amawbia conflict. The issue under contention has always been the denial of basic 
economic resources that form the core means of their livelihood and survival and refusal to pay agreed rent.

Onwudiwe (2004) commented as follows:

Much of the bloody disorder in the northern cities of Kano, Kaduna and Jos is restricted to poorer neighbourhoods, a situation that suggests an economic dimension to this general atmosphere of distrust and violence in the country. In these poor, overcrowded and starved communities, youthful gangs of Muslims and Christians burn down churches and mosques and savagely hack each other to death over trivial provocation. (p. 45)

Next in the line are inflammatory or provocative language/ statements by some members of a community that are easily misinterpreted or related to a previous issue of misunderstanding between individuals or groups from any of the parties. These statements involve cajoling, insulting, blackmailing and castigating, thereby generating acrimony, rancour, bitterness and segregation. These types of statements should be avoided for the interest of peace, harmony and cordial relationship. Alluding to this statement, Ugwu (2009) has noted that '... unguarded utterances and rumours were also principal to religious crises'. Furthermore, the attack and killing of innocent citizens under the guise of protests against the publication of caricatures of the Prophet Muhammad by a Dannish newspaper is another case in point.

\section{Cases of communal crises in Nigeria}

\section{Ife-Modakeke crisis}

The Ife-Modakeke crisis is one of the important negative events in the life of the Yoruba people. It is regarded entirely as an intra-ethnic conflict that has led to the destruction of occupational and vocational trade as well as lives and property. Aja (2007) explained that 'the crisis has lasted over a century and that it has occasioned refugee cases and deeprooted lines of socio-political disharmony'. Ile-Ife is the ancient capital city of Yoruba land. It is situated in the tropical zone within longitude $4.06 \mathrm{E}$ and latitude $7.50 \mathrm{~N}$. Ile-Ife is located about $2.75 \mathrm{~m}$ above sea level and about $78 \mathrm{~km}$ northeast of Ibadan in Oyo state, Nigeria; it has 83 classified urban areas with a population of 148141 according to the 2006 census Federal Government of Nigeria Official Gazette (Fatile \& Awotokun 2009). The Ife-Modakeke crisis lasted for several decades. The Ife people were the native settlers (aborigines) of the famous old Oyo Empire. The Modakekes were originally strangers (refugees) who were allowed a settlement land by the Ooni of Ife out of sympathy.

This Ooni of Ife, Abewelia, ascended the throne in 1839. Crisis started in 1997 soon after the creation of 143 new local governments in 1996, when Modakeke was made the headquarters of Ife east local government council. As the Ife people protested strongly, the military administrator of Osun State, Col. Anthony Obi announced on 14 August 1997 government's decision to relocate the Local Government Area (LGA) headquarters from Modakeke to Oke-Ogbo in the Ilode area of Ile-Ife. Surprisingly, on 16 August 1997, a full-blown violence erupted between the Modakeke and Ife people, which led to a great loss of lives and property. It should be noted that land ownership and boundaries have always been the bone of contention between Ife and Modakeke people (Fatile \& Awotokun 2009).

\section{Aguleri-Umuleri communal conflicts}

Aguleri and Umuleri are two different communities in the southeast of Anambra state of Nigeria. They share common culture and boundary. They were said to be living peacefully before the arrival of colonial masters.

However, with the coming of colonial masters the terrain changed because of their business strategies and the attendant implications. In fact, when the Europeans settled at OtuOcha, the place became a business centre for all towns comprising the two communities.

The situation, therefore, is that as Otu-Ocha grew into a centre of trading and attraction, the land became a commodity with beginning of competition. This, according to Ake (1986) in Nwanegbo (2009), is what happened in the most growing societies, more especially with urbanisation. Although this could be coincidental, but it was during this period that contest for the ownership of the portion of the land, today known as Otuocha, became conflictual, with beginning of court cases, propagandas, framing and reframing of history as well as open wars.

The conflict involving these two communities that lay on the eastern bank of the Omambala (Anambra) river has manifested since 1993 when they had their first recorded fullblown war. Interestingly, the two communities then had three other fierce battles, with the first two coming every 31st year and increasing in intensity of action and extensiveness of spread with each developing phase. These were the 1964, 1995 and 1999 wars. Following each stage of developed conflicts/wars, there were loss of lives and property and the displacement of population with its ensuant consequences (Nwanegbo 2009). Government waded into the conflict and with the assistance of elders and chiefs from both sides succeeded in bringing a halt to protracted crisis. Since then, a peaceful atmosphere has prevailed there.

\section{Zangon-Kataf crisis in Kaduna, Nigeria}

Geographically, Zangon-Kataf are communities in the Zango-Kataf local government area of Kaduna state. They are located on the southeast part of Kaduna state. The Zangon-Kataf crisis is similar to the Ife-Modakeke crisis. It is all between the natives (the aborigines) and the settler elements over the struggle for the possession of landed property and other attachments. The battle was between the Kataf (the Atyaps/natives) and the immigrant settlers (Hausa/Fulani). The Hausa/Fulani were graciously allowed to settle in the land of the Atyaps but soon the settlers became more enterprising in their trade and began to dominate urban areas. Abada (2009) observed this as follows: 
[S]equel to the crisis, there was a cordial relationship that existed between the groups in spite of the difference in religious backgrounds and settlement issues. The Hausa-Fulani group that settled in Zango town which happened to be the commercial nerve of the city was more enterprising commercially than the indigenes or the natives of the town. Even when this existed, it did not hinder or obstruct the harmonious existence of the communities. The manifestation of the difference started with the existence of the Sharia Courts and Christian mission. (p. 476)

In fact, the year 1992 became a watershed in relations between the Atyaps and Hausa-Fulanis because what initially started merely as a difference in setting of a new market location degenerated into an all-out religious violence between the Christian and Muslim communities in Kaduna (Nnoli 2006 in Abada 2009).

The Kaduna state government in an effort to control the situation and restore peace in southern Kaduna instituted a commission of inquiry headed by Justice Rahilla Cudjoeto to ascertain the causes of the conflict.

The commission investigating the conflict had not concluded its public hearings when a more devastating riot broke out in May 1992 in major cities of Kaduna state, which claimed many lives and destroyed vast property. Prior to the riots of May 1992 in southern Kaduna, the two communities of Zangon-Kataf in the Zango-Kataf local government council had been managing and controlling their differences, thereby existing harmoniously and having mutual coexistence. Even when the migrant (Hausa-Fulani) seemed to be wielding a lot of economic and socio-cultural influence against natives (Atyaps), the tension did not build until when extraneous elements created by colonial masters came in (Abada 2009).

\section{Cases of religious conflicts in Nigeria}

Christianity, Islam and African traditional religion are the three major religions in Nigeria. It is pertinent to stress at this point that the battle is always between the two foreign religions, that is, Christianity and Islam.

Sometimes the battle could be between Christians and adherents of African traditional religion. Whenever this happens, Christians attack the adherents of traditional religion. African traditionalists are peace-loving people who never attack others except retaliating attacks from others. Lending credence to this, Captain Rattray, a foreigner in Onyeidu (1998) had admitted this attribute of the traditional religion when he observed that 'the west African's spirit of toleration always seems to me something which African religion could teach the warring sects of Christendom'.

The conflicts usually take place in the northern part of the country. Islamism in northern Nigeria is a multifaceted monster. A large proportion of Muslims are simple honest human beings who follow the moderate teachings of Prophet Mohammed. However, at the slightest provocation, they, without finding out the root of the problem, take sides with their Muslim brothers and are ready to do anything to retaliate and instantly pull out their sharp daggers and knives to fight their common enemy. Although fanatical sects of Islam are in minority in the north, they are extremely dangerous and volatile. When these fanatical Muslims strike, they generally elicit support and sympathy from Muslim brothers (Ugochukwu n.d.).

Maitatsine religious riots of 1980: The majority of Muslim Ummah practice sound religious ideologies. The few extremists within them have often ignited the flame of religious conflicts across the country. For Muslim fanatics, the whole system of nation state and its administration is simply un-Islamic and must be pulled down and replaced with what they would call an Islamic state. The activities of this small proportion of Islamic fundamentalists in Nigeria always step into any potential conflicting situation to unleash religious mayhem on Christians and the country at large (Egodu 2010). These Muslim extremists include Muhammad Marwa Maitatsine, the leader of the Maitatsine group, amongst others. Kano city, the commercial hub of northern Nigeria, became a hot bed of religious fanaticism. The first religious disturbance of note in Nigeria took place in Kano in December 1980. It was masterminded by Muhammad Marwa Maitatsine, a Cameroonian who had his infamous kingdom in the heart of Kano. He first came into the notice of Nigerian authorities in 1962 when he was arrested and imprisoned for 3 months and subsequently deported for treasonable felony. He later came back to settle in Kano, and by 1973 built a band of more than 10000 fanatics (Okwueze 1995).

Towards the end of 1980, Maitastine struck, following a 2-week ultimatum given by Abubakar Rimi, former civilian governor of Kano state, that he should quit the area illegally occupied by his group. The city of Kano was put under siege for 2 weeks by the Maitatsine group armed with all sorts of weapons, including guns. They killed, maimed and wounded thousands of people. Writing on the Kano riots of Okonofua (2011) reveals that:

only several days of fighting resulted in the deaths of 4,177 people in Kano alone before spreading to other northern states including Kaduna (Zaria), Bornu (Maiduguri and Bukumkutu), Gongola (Jimeta, Dobeli, Zango, Yelwa, Va'atita, Rumde, and Nassarawa), and Bauchi (Pantami). (p. 33)

Since the Kano riots of 1980, the Maitastsine disturbance has become almost a yearly ritual. Although Maitatsine died during the 1980 riots, by 1982 his disciples surfaced again, this time in Bulumkutu, which is on the outskirts of Maiduguri, Borno and Kaduna states. About 400 lives were lost and property worth more than $\$ 3 \mathrm{~m}$ was destroyed. In February 1984, the fanatics, now growing in number, attacked a village in Jimeta in former Gongola, now Adamawa state, where 763 causalities were recorded and about 5913 people were displaced. A year later in 1985, in spite of the official report of the then Gongola state police commissioner, Nuhu Aliyu, that his command had advanced intelligence report 
on their activities, the same group struck at Gombe, Bauchi state. On 26 April 1985, more than a hundred people died after about $10 \mathrm{~h}$ of fighting in Gombe (Okwueze 1995).

Some years later, another Maitastsine religious riot occurred in 1990. This, according to Adukwu (2007), was triggered by an Igbo Christian, Gideon Akaluka, who was alleged to have defecated the Muslim Holy Book (the Holy Quor'an). Gideon paid with his life as riotous Muslim youths publicly beheaded him. The riot that followed the incident was wanton, thousands died and victims' property was destroyed with abandon.

The organisation of Islamic conference of 1986 conflict: This has to do with the attempt by former head of state General Babangida to register Nigeria as a member of Islamic State, which was seriously resisted by Christians, and this was called Babangida's 'acid test' (Ekwunife 1992). According to Yahaya (2011), incursion of military into Nigeria's sociopolitical landscape also heighten ethno-religious tensions and conflicts in the country, particularly through the use and manipulation of religion as it happened on the issue of the organisation of Islamic conference (OIC) during the Babangida administration. According to Sani (2007) in Yahaya (2011:29), the Buhari-Idiagbon administration (1984-1985) took Nigeria to the OIC, whilst Sani Abacha (1993-1998) ensured that Nigeria attended the OIC as a full member and went as far as consolidating the membership by introducing the non-profit Islamic banking system. The Abubakar Abdulsalami (19981999) regime adopted Babangida and Abacha's draft constitution on the Sharia appeal courts in the state in the 1999 constitution. The net consequences of these manipulations saw Nigeria on both sides of religious divide, getting alienated and polarised against the very ethics which the military represented and which was not ensuring national unity and integrity.

Riots of 14 October 1991 (Reinhard Bonnke): This time it was the case of a German evangelist Reinhard Bonnke who visited Kano in 1991 for a crusade. There was a peaceful procession initiated by Islamic sect to stop Reinhard Bonnke from having crusade in Kano. The peaceful protest later culminated into violent clashes in spite of all appeals by the Emir and members of his council not to do so and this eventually led to loss of lives and property worth millions of naira. As in the past, the rioters targeted mostly southerners and Christian northerners as they moved from street to street killing people, setting vehicles and houses on fire (Chigozie \& Murtala 2009; Ibenwa 2012).

Zamfara and Kaduna Sharia riots of 21 February 2000: The governors of these states introduced Islamic laws, but at a point Christians revolted. Consequently, this led to wanton destruction of lives and property. When the violence broke out, thousands of people were allegedly killed within the first 2 days. The violence soon spread to other places, and Kafanchan became a refuge town with over 40000 displaced persons (Yahaya 2011).
Kaduna Sharia riots of 21-24 February 2000, reprisal attacks: Following the unprecedented number of southerners massacred in this riot, reprisal attacks took place in Lagos, Aba and Umuahia against northerners, in which thousands of people were killed and property worth millions of naira was destroyed. Based on police reports, 700 people were said to have lost their lives in this conflict, whilst hundreds of people were injured and over 1950 buildings, 746 vehicles, 55 mosques and 123 churches were razed. Sophisticated weapons such as military rocket launchers, bombs, grenades and locally made pistols were used freely (Yahaya 2011).

2006 Onitsha reprisal attack on the Hausa Indigenes: For the inhabitants of Onitsha, 21 February 2006 would remain a sad day in their lives. On this day, hoodlums unleashed an attack on the Hausa community in Anambra state. The attack was to avenge earlier attacks on Christians in Maiduguri, Borno state capital. Reprisal attacks in Onitsha, Anambra state, again revealed the ugly face of religious fanaticism in Nigeria. The protesters left over 50 people dead in Maiduguri, over 30 churches and five hotels burnt whilst many shops and business establishments suspectedly belonging to southern Christians were either vandalised or looted.

In the reprisal attack in Onitsha, the death toll was as high as 100. The development left Borno state governor, Senator Modu Ali Sheriff, and his Anambra counterpart, Dr Chris Ngige, in a bad mood.

Boko-Haram: Boko-Haram was started by its founder Mohammed Yusuf in 2001 in Maiduguri, Borno state.

Their activities assumed a maddening dimension by introduction of suicide bombing in a large scale after April 2011 general elections that brought President Goodluck Jonathan back to power. Out of the 19 states in the north, the most affected were Kano, Kaduna, Niger, Adamawa, Bauch, Yobe, Taraba, Gombe, Borno and Plateau, with the following destructive activities attributed to Boko-Haram:

- The bombing of police force headquarters in Abuja on 16 June 2011, claiming six lives and 73 vehicles destroyed, created an atmosphere of tension.

- Likewise, the bombing of the UN House at Abuja on 26 August 2011 created diplomatic strain between Nigeria and other countries. In this attack, at least 23 persons (11 UN personnel and 12 non-UN personnel) were killed.

- Bomb explosion at St. Theresa's Catholic Church in Madala, Niger state on 25 December 2011 (Okwor 2012).

- Abduction of over 200 Chibok Secondary School girls on 15 April 2014.

- The Nyanya bomb blast at Nyanya motor park on 14 April 2014 with over 88 people dead and 200 injured (Ibenwa 2014).

According to Yahaya (2012), there was another terrorist confrontation by Boko-Haram with security personnel at Mamudo village and the Railway Terminus in Maiduguri on 
29 July 2009. Boko-Haram killed 44 people on 31 August 2015. On 20 September 2015, bombing by Boko-Haram at Monguno killed 27 persons. Bomb blast by Boko-Haram at Yola killed 34 and injured 80 people on 17 November 2015. On 19 April 2016, they attacked Borno, where 30 terrorists were killed and 24 soldiers were wounded. On 11 June 2016, Boko-Haram killed four women in Borno. On 15 June 2016, they attacked a village near Chibok and killed three persons.

\section{Suggestions}

Based on the above-mentioned attacks and destruction, the following recommendations are provided. If these are followed strictly by individuals, groups and governments, the frequent religious and communal conflicts would be reduced to its barest minimum:

1. Dialogue is paramount in conflict management. This is because, by far, it is the most effective means of not only making peace but also managing conflicts. It is also the method by which the contending parties are given the opportunity to air their grievances and chart a course of peaceful settlement. Mutual and unbiased dialogue creates long-term understanding and resolution of conflict. In this case, constructive dialogue between the Christians and Muslims and between communities.

2. Capital punishment must be enshrined into the Nigerian legal system to take care of perpetrators and serve as a deterrent to others.

3. Potential conflicts should be nipped in the bud instead of waiting for these to escalate into crisis. Nigerian leaders must wake up to their responsibilities in being able to observe early warnings and respond proactively, instead of being parochial in handling delicate national issues.

4. Government of Nigeria has to be prudent in its administration, especially in giving people what is due to them.

5. Nigerian traditional rulers and elders are not living up to expectations. They should be prompt to locate these problem areas and devise a proactive means to settle problems using the power of their offices. After all, they are paid for it by the government. They are paid to maintain tranquility and a peaceful environment in the country.

There should be proper orientation of people, particularly the religious sects. Time has changed and it would be archaic to think of evangelising people through a campaign of calumny. Converts are made through persuasion and conviction and not the use of force, which exhibits crude and uncivilised culture. Tolerance and accommodation are the keys.

\section{Summary and conclusion}

The present study has found out that for a long time now the twin phenomena of religion and communal conflicts have taken a large toll of human and material resources, which would have contributed to improving the standard of living and overall national development. These phenomena has taken Nigeria's development pace backwards in comparison to other progressive African countries recording up to $18 \%$ $20 \%$ development pace. Conclusively, realising the enormous harm communal and religious crises have inflicted on the progress of people and the development of nation, it becomes imperative that all hands must be on deck, the government, the communities, the religious organisations and the citizens, in finding a solution to this deadly monster of communalism. Again, if we have to remain one nation with federal government, we have to refrain from the notions and practices that infringe the principles of federalism, in the same vein as we refrain from the habits that negate the cardinal values of national integration. Peace is the beacon of development and progress capped with the popular adage of 'united we stand and divided we fall'. The findings of the study validate the fact that most of the communal crises taking place at present could be traced to colonial legacy which created artificial boundaries that did not take cognisance of kith and kin, linguistic identity and other pluralistic indices competing for interest in a heterogeneous Nigerian nationhood.

\section{Acknowledgements}

We thank those people who assisted us with literature and primary data.

\section{Competing interests}

The authors have declared that no competing interests exist.

\section{Authors' contributions}

C.N.I. was the lead researcher and F.C.U. assisted him in the research.

\section{Ethical consideration}

This article followed all ethical standards for a research without direct contact with human or animal subjects.

\section{Funding information}

This research received no specific grant from any funding agency in the public, commercial or not-for-profit sectors.

\section{Data availability statement}

Data sharing is not applicable to this article as no new data were created or analysed in this study.

\section{Disclaimer}

The views and opinions expressed in this article are those of the authors and do not necessarily reflect the official policy or position of any affiliated agency of the authors. 


\section{References}

Abada, I.M., 2009, 'Inter-communal conflict in Nigeria. A case study of Zangon-Kata 1992 crisis in southern Kaduna', in C.M. Ikejiani (ed.), Peace studies and conflict resolution in Nigeriia, pp. 476-478, Spectrum Books, Ibadan.

Adejo, A.M., 2002, 'Ethnic and communal violence in a plural polity: The Nigerian experience', in C. Angya (ed.), FASS: Journal of Faculty of Arts Seminar Series, p. 248, Starix Books, Makurdi.

Adetula, V.A.O. \& Dung, P.S., 2006, 'Sectarian conflicts in Nigeria and their implications for electoral violence', Paper Prepared for IFFS Seminar on Preventing Electoral Violence in Nigeria, Sheraton Hotel and Towers, Abuja, June 27-28, p. 478.

Adukwu, R.M., 2007, 'Managing conflicts arising from religious extremism: Using Jerusalem council paradigm', in C.O. Ugwu (ed.), Nigeria journal of humanities and social science, pp. 2007-2297, Great AP Express Publishers, Nsukka.

Aja, A.A., 2007, Basic concepts, issues and strategies of peace and conflict resolution in Nigeria-African conflict case studies, pp. 502-503, Kenny and Brothers, Enugu.

Ake, C., 1986, 'Editorial: raison d' etre', African Journal of Political Economy 1(1) $1-I V$.

Anugwom, E.E. \& Oji, P., 2004, 'Ethnic and religious crises in Nigeria: A review of past and present dimension', in M.I. Okwueze (ed.), Religion and societal development: Contemporary Nigerian perspectives, pp. 143-149, Merit International Publications, Lagos.

Bouquet, A.C., 1941, Comparative religion, p. 183, Penguin Books, Middlesex.

Bourdillion, M.F.C., 1990, Religion and society: A text for Africa, p. 183, MAMBO Press, Gweru.

Chigozie, F. \& Murtala., A., 2009, 'Litany of religious conflict in Nigeria', Tell Magazine, 10 August, p. 15

Egodi, U., 2010, 'Being igbo and muslim: The igbo of South-Eastern Nigeria and conversions to Islam, 1930s to recent times', The Journal of African History 51(1), 63

Ekwunife, A.N.O., 1992, Politics and religious intolerance: The Nigerian experience, pp. 13-25, Spiritan Publications, Enugu.

Fatile, J.O. \& Awotokun, K., 2009, 'Ife-modakeke crisis', in C.M. Ikejiani (ed.), Peace studies and conflict resolution in Nigeria, p. 1, Spectrum Books, Ibadan.

Francis, J.D., 2007, 'Peace and conflict studies: An African overview of basic concepts', in G.B. Shedrack (ed.), Introduction to peace and conflict studies in West Africa, p. 20, Spectrum Books, Ibadan.

Ibenwa, C.N. \& Anyaogu, C.N., 2010, 'Religion and inter-communal crisis: A focus on northern Nigeria', in O.D. Nnadozie (ed.), Tropical issues in social sciences, p. 214 Louis Chimez, Nsukka.

Ibenwa, C.N., 2012, 'Fanaticism and religious riots in northern Nigeria: Its implication for societal development', PhD thesis submitted to the department of religion and cultural studies, University of Nigeria, Nsukka, 24 p.
Ibenwa, C.N., 2014, 'Religious conflict and politics in Nigeria: Implications for national development', International Journal of Research in Arts and Social Sciences 7(1), 288

James, P., 2018, 'What Does It Mean Ontologically to Be Religious?', in S. Ames, I. Barns, J. Hinkson, P. James, G. Preece \& G. Sharp (eds.), Religion in a secular age: The struggle for meaning in an abstracted world, p. 70, Arena Publications, Fitzroy.

Nnoli, O., 2006, National security in Africa: A radical perspective, p. 16, PACREP, Enugu.

Nwachukwu, K.O. \& Ibenwa, C.N., 2011, 'Religion and inter-communal crisis in Nigeria', in O.U. Nnadozie (ed.), Simulation exercises for topical issues in social science, p. 11, REK Books, Nsukka.

Nwanegbo, C.J., 2009, 'Inter-communal conflict in the south-eastern Nigeria: A study of Aguleri-Umuleri conflicts', in C.M. Ikejiani (ed.), Peace studies and conflict resolution in Nigeria, pp. 5001-5002, Spectrum Books, Ibadan.

Okeke, V.I., 1998, 'Religion and its place in human society', in B.N. Iffih (ed.), Modern textbook on social science, p. 53, Joen Publishers, Enugu.

Okonofua, B.A., 2011, 'Paths to peacebuilding: Amnesty and the niger delta violence', A Doctoral dissertation, Georgia State University, p. 33, viewed 13 May 2020, from https://scholarworks.gsu.edu/sociology_diss/62.

Okpara, C.I., 2013, 'Boko-Haram and the strategy and tactics of Islamic domination of Nigeria', PhD thesis submitted to political science department, University of Nigeria, Nsukka, $27 \mathrm{p}$.

Okwor, C.O., 2012, 'Religious conflict in Nigeria and national development: Causes and effects', Nsukka Journal of Religion and Cultural Studies 5, 11.

Okwueze, M.I., 1995, 'Religious problems and conflict in Nigeria revisited', in J. Onuoha \& J. Ozioko (eds.), Contemporary issues in social science, p. 73, Acena, Enugu.

Onwudiwe, E., 2004, 'Communal violence and future of Nigeria', Summer: Globa Dialogue 6(3), 4

Onyeidu, S.O., 1998, African traditional religion: The problem of definition, p. 21, EasyQuality Press, Nsukka.

Phil-Eze, P.O., 2009, 'The environmental, peace and conflict in Nigeria', in C.M. Ikejian (ed.), Peace studies and conflict resolution in Nigeria, p. 393, Spectrum Books, Ibadan.

Ugochukwu, I., n.d., Boko-haram Islamism and Nigerian unit, p. 51.

Ugwu, C.O.T., 2009, 'Religious crisis in Kano and Kaduna', in C.M. Ikejiani Clark (ed.), Peace studies and conflict resolution in Nigeria, pp. 521-523, Spectrum Books, Ibadan

Yahaya, A.J., 2011, 'Ethnic and religious conflicts in Kaduna and Plateau states: Implications on socio-economic and political development of Nigeria', PhD thesis presented to the department of religion and cultural studies, University of Nigeria, Nsukka, 29 p.

Yahaya, A.J., 2012, 'Terrorism and its implication for national development', Nsukka Journal of Religion and Cultural Studies 5, 54. 